\title{
Net energy evaluation of feeds and determination of net energy requirements for pigs
}

\author{
Jean Noblet \\ INRA, UMR 1079 SENAH, 35590 Saint-Gilles (France). jean.noblet@rennes.inra.fr
}

\begin{abstract}
Feeds for pigs can be attributed different energy values according to, first, the step considered in energy utilization (DE: digestible energy, ME: metabolizable energy and NE: net energy) and, second, the method used for estimation at each step. Reference methods for evaluating DE content are based on in vivo digestibility measurements; indirect estimates of DE values are obtained from in vitro methods or prediction equations based on chemical characteristics. Methods have also been proposed for estimating urinary energy (and gas energy to a smaller extent) in order to calculate ME content from DE value. The NE values originate from energy balance studies (slaughter methods or, more commonly, indirect calorimetry measurements in respiration chambers) and their compilation allows the calculation of NE prediction equations based on digestible nutrient contents or DE or ME contents. Such equations are applicable to both ingredients and compound feeds. They may differ between origins according to the fractionation method of organic matter or assumptions such as the NE requirement for maintenance (or fasting heat production). These measurements represent the bases for establishment of energy values in feeding tables.

Results indicate that energy digestibility of feeds is negatively affected by dietary fibre content but this negative effect is attenuated with body weight increase, which suggests that feeds should be attributed DE values according to pig BW; in practice, at least two different DE values, one for growing-finishing pigs and one for mature pigs (reproductive sows), are recommended. The energy digestibility of pig feeds can also be affected by feed processing (pelletting, extrusion, etc.). Efficiency of ME utilization for NE averages 74-75\% for conventional pig diets but it is directly dependent on diet chemical composition with efficiencies higher for ME from fat (90\%) or starch (82\%) than from protein or dietary fibre $(60 \%)$. The hierarchy between feeds and results of least-cost formulation are then dependent on the energy system with overestimation of protein rich feeds and underestimation of starch and/or fat rich feeds in the DE or ME systems. The NE system provides an energy value which is the closest estimate of the "true" energy value of a feed; it predicts more accurately the performance of the pigs and allows implementing new feeding approaches such as the use of low protein and/or high fat diets. Energy requirements expressed as DE or ME can be transformed to NE requirements if we assume that the average efficiencies of DE or ME for NE are 71 and $74 \%$, respectively. More sophisticated methods including modeling techniques can also be used for evaluating energy requirements.
\end{abstract}

Key Words: energy requirement, energy value, heat production, net energy, pig

\section{Introduction}

The cost of feed is the most important cost of pig meat production (\#60\%) and the energy component represents the greatest proportion. Therefore, it is important to estimate precisely the energy value of feeds, either for least-cost formulation purposes or for adapting feed supply to energy requirements of animals. Evaluation of energy content of pig feeds is usually based on their digestible (DE) or metabolizable (ME) energy contents. However, the closest estimate of the true energy value of a feed should be its net energy (NE) content which takes into account differences in metabolic utilization of ME between nutrients. In addition, NE is the only system in which energy requirements and diet energy values are expressed on a same basis which should theoretically be independent on the feed characteristics. The objectives of this paper are to review for pig feeds $\mathbf{1 /}$ the methods used for estimating their energy value, 2 / the main factors of variation of digestive and metabolic utilization of energy and $\mathbf{3}$ / the available energy systems. A last part will be 
devoted to the expression of energy requirements of pigs according to the evaluation system for feeds. For all aspects, emphasis will be given to net energy. Complementary or more exhaustive information has been considered in previous reviews (Noblet and Henry, 1993; Noblet, 1996; Noblet and Le Goff, 2001; Noblet and van Milgen, 2004; Noblet, 2006).

\section{Methodological aspects}

Gross energy of feed (GE) is not totally available for meting the requirements of animals since some energy is lost in faeces, in urine, as gas of fermentation (methane, hydrogen) and as heat (or heat increment). The DE content of a feed corresponds to its GE content minus energy losses after digestion in the digestive tract and is obtained as GE minus energy losses in faeces. Even they are related to digestion, energy of gas and heat originating from hindgut fermentation is not considered in the calculation of $\mathrm{DE}$. The ratio between DE and GE corresponds to the digestibility coefficient of energy (DCe). The DE content is usually measured in pigs kept in digestibility cages; the amount of faeces over a minimum of 5 days is either obtained from total collection or estimated according to undigested markers included in the feed. The ME content of a feed is equivalent to the difference between DE content and energy losses in urine and gases. Most of the energy lost in gases is due to methane production. While the energy content of feed, faeces and urine can be measured with pigs kept in metabolism crates, the measurement of methane production necessitates the pig to be housed in a respiration chamber. Consequently, most ME values reported in literature and tables ignore energy losses as methane.

Net energy is defined as ME content minus heat increment (HI) associated with metabolic utilization of ME and the energy cost of ingestion and digestion of the feed; the energy cost corresponding to a normal level of physical activity is also included in the heat increment. In growing or fattening pigs fed above their maintenance energy requirements, only a fraction (so-called $\mathrm{k}_{\mathrm{g}}$ ) of the additional ME supply $(\Delta \mathrm{ME})$, is retained in the body and the other part which corresponds to HI, is lost as heat. Similarly, below

๑ 2007 Sociedade Brasileira de Zootecnia maintenance energy supply, $\triangle \mathrm{ME}$ is used for sparing energy from body reserves with an associated $\mathrm{HI}\left(\mathrm{HI}_{\mathrm{m}}\right)$; the efficiency of utilization of $\mathrm{ME}\left(\mathrm{k}_{\mathrm{m}}\right)$ corresponds then to the ratio $(\Delta \mathrm{ME}$ $\left.\mathrm{HI}_{\mathrm{m}}\right) / \Delta \mathrm{ME}$. But, in practice, only the amount of total energy retained (RE) or total heat production (HP) can be measured directly in animals and $\mathrm{k}_{\mathrm{g}}$ (or $\mathrm{k}_{\mathrm{m}}$ ) or $\mathrm{HI}$ ( or $\mathrm{HI}_{\mathrm{m}}$ ) correspond to the slopes of the relationships between RE or HP and ME intake.

As discussed below, HI of a given feed is not constant over a large range of ME intakes and it depends on physiological factors. For instance, it tends to be lower below than above maintenance energy supply (Noblet et al., 1993, 1994 a,b); it is also lower when ME is used for fat deposition than for protein gain (Noblet et al., 1999). Therefore, for comparing different feeds for their HI or their efficiencies of utilization of $\mathrm{ME}\left(\mathrm{k}_{\mathrm{g}}\right.$ or $\left.\mathrm{k}_{\mathrm{m}}\right)$, it is necessary to calculate these values under comparable conditions such as similar feeding level and/or constant composition of the gain.

It would then be necessary to feed the pigs different energy levels in order to calculate the values of HI or $k$ of a given feed. Such measurements are complex and time-consuming, so that only one feeding level is usually applied. The slopes are then calculated by assuming an estimate of fasting heat production (FHP). The value of FHP is either directly measured in fasted pigs or calculated by extrapolating HP as measured at different energy levels to zero ME intake or estimated from literature. In positive energy balance animals, the NE value corresponding to a given amount of ME intake is then equivalent to the sum of estimated FHP and RE. Such an approach means that, in such animals, the efficiencies of ME for gain and for maintenance are supposed to be the same for a given diet or the efficiency that is calculated corresponds to a combined energy requirement for maintenance and for growth. It also means that the NE value of a feed is directly dependent on the estimate of FHP.

From a practical point of view and in order to avoid any bias in the calculation of NE for a series of feeds, it is then highly suggested to carry out energy balance measurements in comparable pigs (one sex, one breed and the same body-weight range, etc.), to keep them in a temperature-controlled environment (above their critical temperature) and 
to feed them at the same energy level. Under such circumstances, an erroneous estimate of FHP will affect the absolute NE value but not the hierarchy between feeds within a series. Energy retention can be measured either according to the comparative slaughter technique (direct measurement) or calorimetry methods (measurement of heat production) in which energy gain is calculated as the difference between ME intake and heat production. The most commonly used calorimetry method is indirect calorimetry which consists in calculating heat production from oxygen consumption and carbon dioxide production (Brouwer, 1965).

While measurements of DE value and, to a smaller extent, of ME value are easy and can be undertaken on a large number of feeds at a reasonable cost, measurement of NE is far more complex and expensive. The principle is then to carry out a series of NE measurements on different diets and to combine all results in prediction equations of feed NE content, the predictors to consider being available from digestibility experiments. These predictors must be easily available, either from feeding tables or at the laboratory level. According to above considerations, NE measurements can be conducted only on balanced diets and the prediction equations obtained from these measurements are then applied to any type of feed. For DE and ME measurements, measurements are conducted on feeds that can be consumed by the pigs, which means that some ingredients such as protein- or fat-rich ingredients cannot be measured directly. Therefore, they are measured indirectly and included at reasonable levels in feeds and their DE value is estimated according to the so-called difference method or to regression methods.

Measurements of energy values according to reference methods can be used to establish prediction equations of DE, ME and, to a less safe extent, NE contents based on chemical criteria (Le Goff and Noblet, 2001) or other criteria directly available on feeds such as NIRS information or in vitro methods. The in vitro methods that simulate in vivo digestion (Noblet and Jaguelin-Peyraud, 2007) are probably a more reasonable option than physical methods

Measurements of energy values of ingredients conducted on pigs according to reference methods have been compiled and they represent the bases of most feeding tables. Several feeding tables have been published for energy value of pig feeds. Those published recently by INRA and AFZ (Sauvant et al., 2004 a,b) are multi-species tables (pigs, poultry, cattle, sheep, goats, rabbits, horses and fish) and data concerning chemical composition of feeds are identical for all species and representative of ingredients available nowadays in Europe; forages are not concerned. The data for nutritional values were mainly derived from in vivo measurements performed in INRA laboratories or obtained from the literature. The concepts that will be described in the next part of this review have been used for calculation of energy value of most ingredients available for preparing pig feeds.

\section{Energy utilization}

\section{Digestive utilization}

For most pig diets, DCe varies between 70 and $90 \%$ but the variation is larger for ingredients (10 to 100\%; Sauvant et al., 2004). Most of the variation of DCe is related to the presence of dietary fibre (DF) which is less digestible than other nutrients $(<50 \%$ vs $80-100 \%$ for starch, sugars, fat or protein) and reduces the apparent faecal digestibility of other dietary nutrients such as crude protein and fat (Noblet and Perez, 1993; Le Goff and Noblet, 2001). Consequently, DCe is linearly and negatively related to the DF content of the feed (Le Goff and Noblet, 2001). The coefficients relating DCe to NDF are such that NDF or DF essentially dilute the diet. In other terms, even though DF is partly digested by the young growing pig, it provides very little DE to the animal (Noblet and van Milgen, 2004).

Digestibility of energy can be modified by technological treatments. Pelletting, for instance, increases the energy digestibility of feeds by about $1 \%$ (Skiba et al., 2002). However, for some feeds (corn, full fat rapeseed), the improvement can be far more important with subsequent marked DE differences (up to $100 \%$ ) between mash and pellet forms (Skiba et al., 2002; Noblet and Champion, 2003; Noblet, 2006). In that case, pelletting improves fat digestibility.

Energy digestibility is affected by other factors than those related to the diet itself. In growing pigs,

๑ 2007 Sociedade Brasileira de Zootecnia 
DCe increases with increasing BW (Noblet and Shi, 1994; Noblet et al., 2003; Noblet, 2006). The largest effect of BW is observed when adult sows and growing pigs are compared (Noblet and Shi, 1993; Le Goff and Noblet, 2001). The difference due to $\mathrm{BW}$ increase is most pronounced for high fibre diets or ingredients. In the case of adult sows and $60 \mathrm{~kg}$ growing pigs, the DE value is 1.8, 4.2, 6.0, 10.3 and $16.6 \%$ higher in sows for wheat, corn, soybean meal, wheat bran and corn gluten feed, respectively (Sauvant et al., 2004). This improvement of energy digestibility with BW is mainly related to an improved digestive utilization of $\mathrm{DF}$ (via a slower rate of passage in the digestive tract; Le Goff et al., 2002) and the DE difference between adult sows and growing pigs is proportional to the amount of indigestible organic matter as measured in the growing pig (Noblet, 2006). The effect of feeding level on DCe is negligible even in adult sows when lactating sows and gestating sows fed at very different energy supplies are compared (Noblet, 2006). Little information concerning comparative digestibility in piglets and growing pigs is available. Considering that piglets are usually fed low-fibre diets for which the effect of BW is minimized, piglets can, from a practical point of view, be considered as growing pigs with regard to digestive utilization of energy.

\section{$M E: D E$ ratio}

In growing pigs, average energy loss in methane is equivalent to $0.4 \%$ of DE intake (Noblet et al., 1994). In sows fed at maintenance level, methane production is 2 to 3 times higher and may reach up to $3 \%$ of DE intake in sows fed very high fibre diets (Ramonet et al., 2000; Le Goff et al., 2002; Noblet and Le Goff, 2001). From the compilation of literature data conducted by Le Goff et al. (2002) and unpublished data from our laboratory, Noblet et al. (2004) proposed that methane energy is equivalent to 0.67 and $1.33 \mathrm{~kJ}$ per $\mathrm{g}$ of fermented DF in growing pigs and adult sows, respectively.

Energy loss in urine represents a variable percentage of DE since urinary energy depends greatly on the urinary nitrogen excretion. At a given stage of production, urinary nitrogen excretion depends mainly on the (digestible) protein content of the diet. Consequently, the ME:DE ratio is linearly related to the dietary protein content (Noblet and Perez, 1993; Le Goff and Noblet, 2001). In most situations, the ME:DE ratio of complete feeds is approximately 0.96 . However, this mean value cannot be applied to single feed ingredients. The most appropriate solution is then to estimate urinary energy $(\mathrm{kJ} / \mathrm{kg}$ DM intake) from urinary nitrogen $(\mathrm{g} / \mathrm{kg}$ DM intake). The following equations have been proposed:

\section{Urinary energy in pigs = $192+31 x$ Urinary nitrogen \\ Urinary energy in sows = $217+31 x$ Urinary nitrogen}

for growing pigs and adult sows, respectively. For implementing these equations to feed ingredients, it can be assumed that urinary nitrogen represents $50 \%$ of digestible nitrogen or $40 \%$ of total nitrogen (Noblet et al., 2003).

\section{Metabolic utilization of ME}

From measurements conducted on a large set of diets, Noblet et al. (1994) showed that the efficiency of ME for net energy in growing pigs $(\mathrm{kg})$ varied with chemical characteristics $(\mathrm{g} / \mathrm{kg}$ $\mathrm{DM}$ ) according to the following equation:

$$
\begin{gathered}
\mathrm{k}_{\mathrm{g}}=74.7+0.036 \times \text { Ether extract }+0.009 \\
\times \text { Starch }-0.023 \times \text { Crude Protein } \\
-\mathbf{0 . 0 2 6} \times \text { ADF }(\text { RSD }=1.2)
\end{gathered}
$$

A comparable equation was proposed for adult sows fed at their maintenance level (Noblet et al., 1993). The variations in $\mathrm{k}$ are due to differences in efficiencies of ME utilization between nutrients with the highest values for fat ( 90\%) and starch $(\sim 82 \%)$ and the lowest ( $60 \%)$ for DF and crude protein (Noblet et al., 1994). These values were confirmed in recent trials (van Milgen et al., 2001). These differences in efficiencies between nutrients also mean that heat increment (per unit of energy) associated with metabolic utilization of energy is higher for crude protein and DF than for starch or ether extract. Measurements conducted in pigs which differed for their BW and the composition of BW gain suggest that the efficiency of ME for NE is little affected by the composition of BW gain, at least under most practical conditions

๑) 2007 Sociedade Brasileira de Zootecnia 
(Noblet et al., 1994). Similarly, the ranking between nutrients for efficiencies is similar in adult sows fed at maintenance level and in growing pigs. These results have been confirmed in recent trials (Noblet, 2006). Finally, the heat increment associated with protein utilization, either retained as protein or catabolized, is constant (van Milgen et al., 2001). This means that the NE value of dietary $\mathrm{CP}$ is not dependent on its final utilization.

\section{Energy systems}

\section{$D E, M E$ and NE systems}

Apart from direct measurement on pigs, the DE and ME values of raw materials can be obtained from feeding tables (NRC, 1998; Sauvant et al., 2004 a,b). But the utilization of these tabulated values should be restricted to ingredients having chemical characteristics similar or close to those in the tables. As illustrated in the previous section, DCe is affected by BW of the animals. It is therefore appropriate to use $\mathrm{DE}$ and ME values adapted to each BW class. However, from a practical point of view, it is suggested to use only two values, one for $60 \mathrm{~kg}$ pigs which can be applied to piglets and growing-finishing pigs and one for adult pigs applicable to both pregnant and lactating sows. The DE content of compound feeds can be obtained by adding the DE contributions of ingredients and assuming no interaction, which is usually the case. When the actual composition of the feed is unknown, the possibility is to use prediction equations based on chemical criteria (Le Goff and Noblet, 2001) or estimates from near infrared or in vitro methods (Noblet and JaguelinPeyraud, 2007).

All published NE systems for pigs combine the utilization of ME for maintenance and for growth (Just, 1982; Noblet et al., 1994) or for fattening (Schiemann et al., 1972) by assuming similar efficiencies for maintenance and energy retention. The system used in the Netherlands (CVB, 1994) has been adapted from the equations proposed by Schiemann et al. (1972). The system proposed by Noblet et al. (1994) and applied in the INRA \& AFZ feeding tables (Sauvant et al., 2004 a,b) is based on a large set of measurements (61 diets). The NE prediction equations that have been generated from these measurements are given in Table 1. They are applicable to ingredients and compound feeds and at any stage of pig production (Noblet, 2006). It is important to point out that different DE values or digestible nutrient contents should be used in growing-finishing pigs and adult sows with two subsequent NE values. Reliable information on digestibility of energy or of nutrients is then necessary for prediction of $\mathrm{NE}$ content of pig feeds. In fact, this information represents the most limiting factor for predicting energy values of pig feeds.

The INRA-AFZ feeding tables provide values of digestible energy (DE), metabolizable energy (ME) and net energy (NE), as well as digestibility coefficients of major nutrients and organic matter (Sauvant et al., 2004). More details are provided in other review papers, especially for estimating the energy value of ingredients whose chemical characteristics are slightly different from those listed in the feeding tables (Noblet et al., 2003; Noblet and Tran, 2004; Noblet, 2006). It must be stressed that the energy values for energy and digestibility coefficients have been obtained only from literature values, thus excluding a copy/paste of previous feeding tables. The concepts used originate from studies conducted at INRA over the last 20 years with two major innovations for pigs: net energy instead of DE or ME values and energy value dependent on the pig physiological stage. For simplification purposes, two stages were considered: the 50-70 $\mathrm{kg}$ growing pig (the data

Table 1 - Equations for prediction of net energy in feeds for growing pigs (NEg; MJ/kg dry matter; composition as g per kg of dry matter; from Noblet et al., 1994; 2004).

\begin{tabular}{lc}
\hline Equation $^{\mathrm{a}}$ & RSD, \% \\
\hline $\mathrm{NEg} 2 \mathrm{a}=0.0113 \times \mathrm{DCP}+0.0350 \times \mathrm{DEE}+0.0144 \times \mathrm{ST}+0.0000 \times \mathrm{DCF}+0.0121 \times \mathrm{DRes}$ & 2.0 \\
$\mathrm{NEg} 2 \mathrm{~b}=0.0121 \times \mathrm{DCP}+0.0350 \times \mathrm{DEE}+0.0143 \times \mathrm{ST}+0.0119 \times \mathrm{SU}+0.0086 \times$ DRes & 2.4 \\
$\mathrm{NEg} 4=0.703 \times \mathrm{DE}-0.0041 \times \mathrm{CP}+0.0066 \times \mathrm{EE}-0.0041 \times \mathrm{CF}+0.0020 \times \mathrm{ST}$ & 1.7 \\
$\mathrm{NEg} 7=0.730 \times \mathrm{ME}-0.0028 \times \mathrm{CP}+0.0055 \times \mathrm{EE}-0.0041 \times \mathrm{CF}+0.0015 \times \mathrm{ST}$ & 1.6
\end{tabular}

${ }^{a}$ CF: Crude Fibre, CP: crude protein, EE: ether extract, ST: starch, DCP: digestible CP, DEE: digestible EE, DCF: digestible CF, DRes: digestible residue (i.e., difference between digestible organic matter and other digestible nutrients considered in the equation). 
can be applied to fast growing animals between 10 to $150 \mathrm{~kg}$ live weight) and the adult sow (the results can be used for both gestation and lactation).

\section{Comparison of energy systems}

From previous observations on energy utilization in pigs, it is obvious that the hierarchy between feeds obtained in the DE or ME systems may differ in the NE system according to their chemical composition. Since NE represents the best compromise between the feed energy value and energy requirement of the animal, the energy value of protein or fibrous feeds will be overestimated when expressed on a DE (or ME) basis. On the other hand, fat or starch sources are underestimated in a DE system (Noblet et al., 2001; Sauvant et al., 2004 a,b; Noblet, 2006; Table 2). With regard to NE for pigs, several systems have been proposed over the last 40-50 years (Noblet and van Milgen, 2004; see above). The INRA proposal (Noblet et al., 1994; 2004) is probably the most advanced system and it has been validated both by calorimetry measurements and growth trials (Le Bellego et al., 2001; Noblet et al., 2001; Le Goff et al., 2002; Noblet, 2006).

Table 2 - Relative DE, ME and NE values of ingredients for growing pigs ${ }^{\mathrm{a}}$.

\begin{tabular}{lrrrc}
\hline & DE & ME & NE & $\begin{array}{c}\text { NE/ME, } \\
\text { \% }\end{array}$ \\
\hline Animal fat & 243 & 252 & 300 & 90 \\
Corn & 103 & 105 & 112 & 80 \\
Wheat & 101 & 102 & 106 & 78 \\
Reference diet & 100 & 100 & 100 & 75 \\
Pea & 101 & 100 & 98 & 73 \\
Soybean (full-fat) & 116 & 113 & 108 & 72 \\
Wheat bran & 68 & 67 & 63 & 71 \\
Soybean meal & 107 & 102 & 82 & 60 \\
\hline
\end{tabular}

a From Sauvant et al. (2004). Within each system, values are expressed as percentages of the energy value of a diet containing $68 \%$ wheat, $16 \%$ soybean meal, $2.5 \%$ fat, $5 \%$ wheat bran, $5 \%$ peas and $4 \%$ minerals and vitamins.

As previously mentioned, it is extremely important to use the same energy system for expressing the diet energy values and the animal energy requirements; in addition, energy values provided by different NE systems cannot be combined. From that point of view, the only energy system in which the requirements are the most independent on the diet characteristics is the NE

๑ 2007 Sociedade Brasileira de Zootecnia system. This is illustrated by several growth trials, especially conducted with variable dietary fat or $\mathrm{CP}$ levels that show that the energy cost is independent on diet composition when expressed on a NE basis. On the other hand, on DE or ME bases, the energy cost is increased when CP content is increased or fat content is decreased (Table 3; Noblet, 2006).

Table 3 - Performance of growing-finishing pigs according to energy system and diet characteristics ${ }^{\mathrm{a}}$.

\begin{tabular}{cccc}
\hline Energy system & DE & ME & NE \\
\hline Trial 1: Added fat (\%) & & \\
0 & 100 & 100 & 100 \\
2 & 100 & 100 & 100 \\
4 & 99 & 99 & 100 \\
6 & 98 & 98 & 100 \\
Trial 2: crude protein content & $(\mathbf{3 0 - 1 0 0} \mathbf{~ k g )}$ \\
Normal & 100 & 100 & 100 \\
Low & 96 & 97 & 100 \\
Trial 3: crude protein content & $(\mathbf{9 0 - 1 2 0} \mathbf{~ k g )}$ \\
Normal & 100 & 100 & 100 \\
Low & 97 & 98 & 100 \\
\hline
\end{tabular}

${ }^{\text {a }}$ Energy requirements (or energy cost of BW gain) for similar daily BW gain and composition of BW gain; values are expressed relative to the energy requirement (or energy cost of BW gain) in the control treatment (considered as 100; values in bold characters); from de la Llata et al. (2001), Noblet (2006) and unpublished data.

\section{Energy requirements}

Energy requirements are expressed on different bases. In ad libitum fed pigs, they consist mainly in fixing the diet energy density according to regulation of feed intake (appetite), growth potential of the pig, climatic factors or economical considerations. In restrictively fed growing pigs or in reproductive sows, it is necessary to define feeding scales according to expected performance or estimated requirements. In more sophisticated or more theoretical approaches (factorial approach or modeling approach), it is necessary to determine the components of energy requirements (maintenance, growth, milk production, thermoregulation, etc). Whatever the level of approach, most trials and recommendations were conducted according to DE and ME estimates for feeds and conclusions were expressed as DE or ME requirements. These recommendations were obtained with rather 
conventional feeds, i.e. cereals-soybean meal based diets whose efficiency of ME utilization for NE in growing pigs was close to $74 \%$ (Table 2); this also means that the NE:DE ratio of such feeds would be $71 \%$. The proposal is then to estimate the NE recommendations (diet energy density, daily energy requirements, components of energy requirements, etc.) as $\mathrm{DE}$ or $\mathrm{ME}$ requirements multiplied by 0.71 or 0.74 , respectively. Our calorimetry studies have shown that absolute values of efficiencies of ME for NE differed slightly according to BW or genotype in growing pigs (Noblet et al., 1994) or were higher for maintenance fed adult sows than for growing pigs (Noblet et al., 1993). But that difference was not dependent on diet characteristics or, in other words, the magnitude of the difference was identical for all nutrients (Noblet, 2006). This means that the above proposal for calculating NE requirements is applicable at any stage of pig production, including pregnant or lactating sows or growing pigs with different growth potential. Since the most reliable and accurate NE equations have been obtained in growing pigs, it is proposed to use these NE equations at all stages of pig production; requirements are then expressed according to a growing pig NE value (Noblet, 2006). However, these growing pig NE values should differ according to pig BW or physiological stage; in practice, only two NE values should be used, one for growing pigs including piglets and one for adult sows, either pregnant or lactating (INRA \& AFZ, 2004).

\section{Conclusion}

This review indicates that energy value of pig feeds can be measured according to different criteria (DE, ME or NE). The most advanced and practically applicable energy evaluation system appears the NE system proposed by Noblet et al. (1994) for which energy values of most ingredients used in pig diets are available (Sauvant et al., 2004). In addition, these authors have proposed energy values that are different for growing and adult pigs. This system has been widely used in Europe and internationally in many major feed companies. This review also indicates that the relative energy density or the hierarchy between ingredients depends on the energy system with considerable variations between ingredients or compound feeds when either fat or crude protein contents deviate from values in standard diets. Even it has not been considered in detail in this review, the change from DE or ME systems to a NE system is usually associated with a shift in diet composition with lower crude protein contents and slightly higher fat levels. Finally, significant improvements in prediction of energy value of pig feeds will come from an improved knowledge of energy and nutrients digestibility, which depends on chemical characteristics of the feed, (bio)technological treatments and animal factors. Unfortunately, current information is insufficient to take this systematically into consideration and it should be a promising area for future research.

\section{Literature cited}

BROUWER, E. Report of sub-committee on constants and factors. In: Blaxter K.L. (Ed.) Energy Metabolism. Proc. 3rd Symp. held at Troon, Scotland, May, 1964. EAAP Publication $\mathrm{N}^{\circ}$ 11, UK: Academic Press. p.441-443.1965.

CVB. Veevoedertabel. Gegevens over voederwarde verteerbaarheid en samenstelling. CVB, Lelystad, The Netherlands. 1994

DE LA LLATA, M.; DRITZ, S.S.; TOKACH, M.D. et al. Effect of dietary fat on growth performance and carcass characteristics of growing-finishing pigs reared in a commercial environment. J. Anim. Sci., v.79, p.2643-2650, 2001.

JUST, A. The net energy value of balanced diets for growing pigs. Livest. Prod. Sci., v.8, p.541-555, 1982.

LE BELLEGO, L.; VAN MILGEN, J.; NOBLET, J. Energy utilization of low protein diets in growing pigs. J. Anim. Sci., v.79, p.1259-1271, 2001.

LE GOFF, G.; NOBLET, J. Comparative digestibility of dietary energy and nutrients in growing pigs and adult sows. J. Anim. Sci., v.79, p.2418-2427, 2001.

LE GOFF, G.; VAN MILGEN, J.; NOBLET, J. Influence of dietary fibre on digestive utilization and rate of passage in growing pigs, finishing pigs, and adult sows. Anim. Sci., v. 74, p.503-515, 2002.

LE GOFF, G.; LE GROUMELLEC, L.; VAN MILGEN, J. et al. Digestive and metabolic utilization of dietary energy in adult sows: influence of level and origin of dietary fibre. Br. J. Nutr., v.87, p.325-335, 2002.

LE GOFF, G.; DUBOIS, S.; VAN MILGEN, J. et al. Influence of dietary fibre level on digestive and metabolic utilisation of energy in growing and finishing pigs. Anim. Res., v.51, p.245259, 2002.

NOBLET, J.; SHI, X.S. Comparative digestibility of energy and nutrients in growing pigs fed ad libitum and adult sows fed at maintenance. Livest. Prod. Sci., v.34, p.137-152, 1993.

NOBLET, J.; HENRY, Y. Energy evaluation systems for pig diets: a review. Livest. Prod. Sci., v.36, p.121-141, 1993.

NOBLET, J.; SHI, X.S.; DUBOIS, S. Metabolic utilization of dietary energy and nutrients for maintenance energy requirements in sows: basis for a net energy system. Br. J. Nutr., v.70, p.407-419, 1993.

NOBLET, J.; PEREZ, J.M. Prediction of digestibility of nutrients and energy values of pig diets from chemical analysis. J. Anim. Sci., v.71, p.3389-3398, 1993.

${ }^{\circledR} 2007$ Sociedade Brasileira de Zootecnia 
NOBLET, J.; SHI, X.S. Effect of body weight on digestive utilization of energy and nutrients of ingredients and diets in pigs. Livest. Prod. Sci., v.37, p.323-338, 1994.

NOBLET, J.; FORTUNE, H.; SHI, X.S. et al. Prediction of net energy value of feeds for growing pigs. J. Anim. Sci., v.72, p.344-354, 1994a.

NOBLET, J.; SHI, X.S.; DUBOIS, S. Effect of body weight on net energy value of feeds for growing pigs. J. Anim. Sci. v.72, p.648-657, 1994b.

NOBLET, J. Digestive and metabolic utilization of dietary energy in pig feeds: comparison of energy systems. In: P.C. Garnsworthy, J. Wiseman, and W. Haresign (ed.) Recent advances in Animal Nutrition. pp 207-231. Nottingham University Press, Nottingham, U.K. 1996.

NOBLET, J.; KAREGE, C.; DUBOIS, S. et al. Metabolic utilization of energy and maintenance requirements in growing pigs: effect of sex and genotype. J. Anim. Sci., v. 77, p.1208-1216, 1999.

NOBLET, J.; LE BELLEGO, L.; VAN MILGEN, J. et al. Effects of reduced dietary protein level and fat addition on heat production and nitrogen and energy balance in growing pigs. Anim. Res., v.50, p.227-238, 2001.

NOBLET, J.; LE GOFF, G. Effect of dietary fibre on the energy value of feeds for pigs. Anim. Feed Sci. Technol., v.90, p.35$52,2001$.

NOBLET, J.; CHAMPION, M. Effect of pelleting and body weight on digestibility of energy and fat of two corns in pigs. J. Anim. Sci., v. 81, Suppl. 1, p.140, 2003.

NOBLET, J.; BONTEMS, V.; TRAN, G. Estimation de la valeur énergétique des aliments pour le porc. Prod. Anim., v.16, p.197-210, 2003

NOBLET, J.; SÈVE, B.; JONDREVILLE, C. Valeurs nutritives pour les porcs. In: Tables de composition et de valeur nutritive des matières premières destinées aux animaux d'élevage: porcs, volailles, bovins, ovins, caprins, lapins, chevaux, poissons. D. Sauvant, J.M. Perez \& G. Tran (Eds), INRA Editions, Versailles, p.25-35, 2004a.

NOBLET, J.; SÈVE, B.; JONDREVILLE, C. Nutritional values for pigs. In: Tables of composition and nutritional value of feed materials: pigs, poultry, cattle, sheep, goats, rabbits, horses, fish. D. Sauvant, J.M. Perez \& G. Tran (Eds) Wageningen Academic Publishers, Wageningen and INRA Editions, Versailles, p.25-35, 2004b.

NOBLET, J.; VAN MILGEN, J. Energy value of pig feeds: Effect of pig body weight and energy evaluation system. J.
Anim. Sci., v.82, n.13. p.E. Suppl., E229-E238. (http:// www.asas.org/symposia/04esupp/E229.pdf), 2004.

NOBLET, J.; TRAN, G. Estimation of energy values of feeds for pigs. Feed Mix, v. 11, n. 4, p.16-19, 2004. also available at: http://www.inapg.inra.fr/ens_rech/dsa/afz/tables/ energy_pig.htm

NOBLET, J.; JAGUELIN-PEYRAUD, Y. Prediction of digestibility of organic matter and energy in the growing pig from an in vitro method. Anim. Feed Sci. Technol., (in press), 2007.

NOBLET, J. Recent advances in energy evaluation of feeds for pigs. In: Recent advances in Animal Nutrition 2005, Eds P.C. Garnsworthy and J. Wiseman. Nottingham University Press, Nottingham. pp. 1-26. 2006.

NRC. Nutrient Requirements of Swine. 10th ed. Natl. Acad. Press, Washington, DC. 1998.

RAMONET, Y.; VAN MILGEN, J.; DOURMAD, J.Y. et al. The effect of dietary fibre on energy utilisation and partitioning of heat production over pregnancy in sows. Br. J. Nutr., v.84, p. 85-94, 2000.

SAUVANT, D.; PEREZ, J.M.; TRAN, G. Tables de composition et de valeur nutritive des matières premières destinées aux animaux d'élevage: porcs, volailles, bovins, ovins, caprins, lapins, chevaux, poissons. D. Sauvant, J.M. Perez \& G. Tran (Eds), INRA Editions, Versailles. 2004a.

SAUVANT, D.; PEREZ, J.M.; TRAN, G. Tables of composition and nutritional value of feed materials: pigs, poultry, cattle, sheep, goats, rabbits, horses, fish. D. Sauvant, J.M. Perez \& G. Tran (Eds). Wageningen Academic Publishers, Wageningen and INRA Editions, Versailles. 2004b.

SAUVANT, D.; PEREZ, J.M.; TRAN, G. Tablas de composición y de valor nutritivo de las materias primas destinadas a los animales de interés ganadero: cerdos, aves, bovinos, ovinos, caprinos, conejos, caballos, peces. Ediciones Mundi Prensa, Madrid, Spain. 2004

SCHIEMANN, R.; NEHRING, K.; HOFFMANN, L. et al. Energetische Futterbevertung und Energienormen. VEB Deutscher Landwirtschatsverlag, Berlin, 344. pp. 1972.

SKIBA, F.; NOBLET, J.; CALLU, P. et al. Influence du type de broyage et de la granulation sur la valeur énergétique de la graine de colza chez le porc en croissance. Journ. Rech. Porcine Fr., v.34, p.67-74, 2002.

VAN MILGEN, J.; NOBLET, J.; DUBOIS, S. Energetic efficiency of starch, protein, and lipid utilization in growing pigs. J. Nutr., v.131, p.1309-1318, 2001. 